\title{
SYMPOSIUM: A FOCUS ON ETHICS IN INTERNATIONAL COURTS AND TRIBUNALS
}

\section{ETHICAL CONDUCT IN INTERNATIONAL CRIMINAL COURTS: WHOSE ETHICS?}

\author{
Elena Cima* and Makane Moïse Mbengue**
}

Ethics plays a crucial role in international adjudication, in particular in the context of international criminal proceedings where the liberty of the accused is at stake. Criminal courts have been trying to create an "international judicial culture" based on shared ethical standards. In doing so, however, they are constantly faced with an obstacle inherent in the very idea of ethics: the impossibility of defining what constitutes "ethical conduct" divorced from one's culture, tradition, legal system, or professional background. This contribution intends to explore the complexity of trying to define the contours of ethical standards in international criminal proceedings, in particular in the absence of precise written rules, by focusing on the Furund ̌ija case. Even when rules are codified, however, they often remain open to divergent interpretations depending on one's cultural, social, and legal background. Ultimately, it is not simply a matter of codifying ethical rules but, more importantly, of agreeing on "whose ethics" these rules should reflect.

\section{The Centrality of Ethics in International Adjudication}

Before taking up their respective duties, the members of the International Criminal Court (ICC) are required to make the following declaration, which is not much different from the oath or affirmation judges in many countries must take before performing the duties of their office:

I solemnly undertake that I will perform my duties and exercise my powers as a judge of the International Criminal Court honorably, faithfully, impartially and conscientiously, and that I will respect the confidentiality of investigations and prosecutions and the secrecy of deliberations. ${ }^{1}$

These declarations might vary in content, but the importance of ethics as a condition of being called to the bench remains a constant theme. ${ }^{2}$ The independence and impartiality of judges are overwhelmingly accepted as fundamental prerequisites of the rule of law, as they ensure the protection of one of the most fundamental human rights: the right to a fair trial. ${ }^{3}$ In the international context, the right to a fair trial and, as a corollary, the centrality of ethical conduct on the part of both judges and counsel is perhaps most important in criminal courts and tribunals, as these

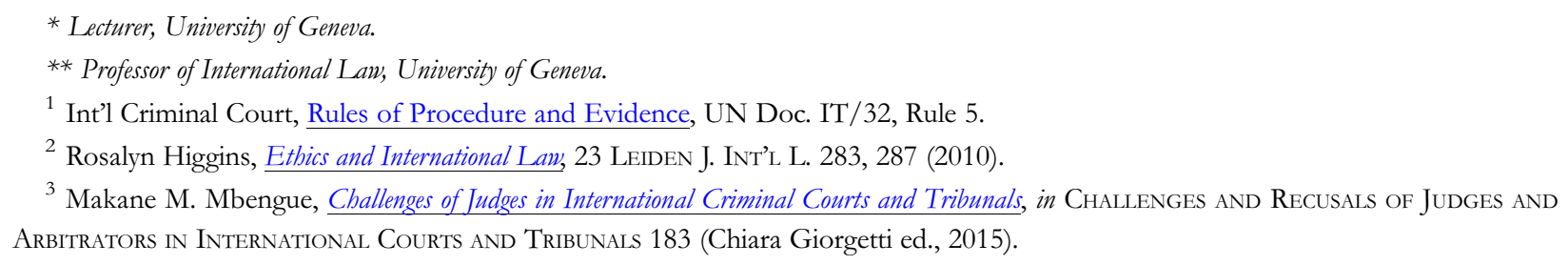

The American Society of International Law, Elena Cima and Makane Moïse Mbengue (C) 2019. This is an Open Access article, distributed under the terms of the Creative Commons Attribution licence (http://creativecommons.org/licenses/by/4.0/), which permits unrestricted re-use, distribution, and reproduction in any medium, provided the original work is properly cited. 
courts pronounce on the responsibility of individuals for international crimes, and their decisions directly impact the liberty of the accused. ${ }^{4}$

If ethics is a constant and always present theme, how is it defined and what does it involve? Given that international judges, as well as international lawyers, come from very varied backgrounds, there is not necessarily a common understanding as to whether certain behaviors are, or are not, ethical. In judicial proceedings with judges from a wide variety of cultures, is it possible to talk about an "international judicial culture" with common ethical standards concerning matters like honesty, impartiality, and diligence? Similarly, do the diverse individuals in the Office of the Prosecutor (OTP) and in the defense bar have a common understanding of ethical standards? In other words, when we talk about "ethics," whose ethics are we talking about? The ethics of each individual judge or lawyer? Or are there absolute ethical principles that guide their behavior, or even a universal morality that all international courts are called upon to uphold?

\section{"It Seems We Look at Things Differently"}

The term etbics—which derives from ancient Greek $\hat{\eta} \theta$ o (èthos), meaning character, custom, or habit—refers to that branch of philosophy that studies the conduct of human beings and the criteria by which behavior and choices are evaluated. It encompasses both the set of norms and values that regulate an individual's behavior in relation to others, and criteria to judge human behavior with respect to good and evil or, in simpler terms, to distinguish between right and wrong.

The set of norms and values that regulate judicial conduct are referred to as judicial ethics. Three key values are fundamental in guiding judicial conduct: independence, impartiality, and diligence. Independence refers to the lack of external forms of influence on adjudication, whether direct or indirect, ${ }^{6}$ while impartiality concerns the internal predisposition of the adjudicator, requiring fair and balanced treatment of the parties and forbidding any bias or personal prejudice. Diligence, finally, refers to the faithful fulfillment of duties and can include integrity, confidentiality, propriety, equality, competence, and diligence stricto sensu. ${ }^{7}$

In domestic legal systems, standards of judicial ethics are old and well-established, and the meanings of independence, impartiality, and diligence are relatively clear and univocal. On the other hand, it is less apparent what their meanings should be in the context of international courts. ${ }^{8}$ This is because the meanings of independence, impartiality, and diligence — just as the meaning of ethics more broadly_are culture-specific and nearly impossible to define when divorced from culture, tradition, legal system, or professional background. Depending on these factors, each of us might have different views on what constitutes ethical or unethical behavior.

Similarly, views may diverge regarding counsel's duty to act "honorably, independently, and freely" and to be "respectful and courteous in his or her relations with the Chamber." Belonging to a civil law rather than a common law tradition, for instance, can influence one's approach to ethics. In her work at the ICJ, Rosalyn Higgins witnessed her "civil law friends" adopt an approach that differed from hers in matters concerning counsels' conduct. She noticed, for example, that certain behavior — such as introducing a new argument or document at a stage in the pleading when the opposing counsel had no opportunity to respond-deeply disturbed her and felt

\footnotetext{
${ }^{4}$ Id.

${ }^{5}$ Higgins, supra note 2, at 288.

${ }^{6}$ Burgh House Principles on the Independence of the International Judiciary, 1.

${ }^{7}$ Int'l Criminical Court, Code of Judicial Ethics, ICC-BD/02-01-05 (2005).

${ }^{8}$ Ruth Mackenzie \& Philippe Sands, International Courts and Tribunals and the Independence of the International Judge, 44 HARv. INT'L L. J. 271, 275 (2003).

${ }^{9}$ Int'l Criminal Court, Code of Professional Conduct for Counsel arts. 6 \& 7, ICC-ASP/4/Res.1 (2005).
} 
professionally inappropriate and unethical, yet warranted "no more than a resigned shrug" from her civil law colleagues on the Court. ${ }^{10}$

\section{Attempts to Codify "Common" Ethical Standards}

This brief account demonstrates the difficulty in creating an "international judicial culture," in the sense of a shared understanding "of how to play the game in the courtroom and a consensus on basic standards for ethical and professional conduct." 11 To this end, international criminal courts and tribunals have developed and codified a number of guidelines and principles. Some of these institutions, including the ICC, have complemented their founding documents by adopting codes of ethics to further specify the obligations inherent in the exercise of the judicial office and in practicing before the court. ${ }^{12}$ Specifically, the ICC has developed detailed rules and procedures governing the independence and impartiality of its judges, which can be found in its Statute, in the Rules of Procedure and Evidence, and in the binding Code of Judicial Ethics. ${ }^{13}$ The Court has also developed comprehensive ethical standards for defense counsel, similar to those developed by the International Criminal Tribunal for the former Yugoslavia (ICTY) and by the International Criminal Tribunal for Rwanda. ${ }^{14}$ However, these rules remain open to divergent interpretations depending on one's cultural, social, and legal background. For example, Article 4 of the Code of Judicial Ethics provides that judges shall "ensure the appearance of impartiality in the discharge of their judicial functions," while Article 5 requires judges to "conduct themselves with probity and integrity." Once again, the meaning of impartiality, probity, or integrity might vary in different legal systems or national cultural traditions.

Take the example of the requirement of impartiality. The ICTY Appeals Chamber in its July 21, 2000 judgment in the Furund $\check{z} j$ a case, relying on the jurisprudence of the European Court of Human Rights, established that the requirement of impartiality demands that a tribunal is "not only genuinely impartial, but also appears to be impartial," and that to assess the "appearance of impartiality," a tribunal should consider whether the circumstances would lead a reasonable and informed observer to apprehend bias. ${ }^{15}$ This interpretation, which seems to have set the standard for the impartiality of judges in international criminal proceedings and has been adopted by other courts and tribunals, ${ }^{16}$ differs from the rule in certain common law countries such as the United Kingdom, where the courts find it unnecessary "to require that the court should look at the matter through the eyes of a reasonable man, because the court has first to ascertain the relevant circumstances from the available evidence, knowledge of which would not necessarily be available to an observer in court at the relevant time."17

\footnotetext{
${ }^{10}$ Higgins, supra note 2, at 287.

${ }^{11}$ Frederik Harhoff, It's All in the Process: Reflections on the Relation Between International Criminal Trials and International Humanitarian Law, 78 Nordic J. Int'L L. 469, 479 (2010).

12 Anja Seibert-Fohr, International Judicial Ethics, in The Oxford Handbook of International Adjudication (Cesare Romano et al. eds, 2013).

${ }^{13}$ Rome Statute of the International Criminal Court, UN Doc. A/CONF.189/9, 37 ILM 999 (July 17, 1998); Int'l Criminal Court, supra note 1; Int'l Criminal Court, supra note 7.

${ }^{14}$ Int'l Crim. Trib. for the Former Yugoslavia, Code of Professional Conduct for Counsel Appearing before the International Tribunal (amended July 22, 2009); Int'l Crim. Trib. for Rwanda, Code of Professional Conduct for Defense Counsel (amended Mar. 14, 2008).

${ }^{15}$ Prosecutor v. Anto Furundžija, Case No. IT-95-17/1-A, Appeal Judgment, paras. 182, 189 (Int'l Crim. Trib. for the Former Yugoslavia, July 21, 2000).

16 See Prosecutor v. Karemera (Édouard), Case No. ICTR-98-44-T, Decision on Appeals Chamber Remand on the Right of the Accused to be Present at Trial (Nov. 28, 2007).

${ }^{17}$ R v. Gough, [1993] A.C. 646 at 661, as quoted in Furundřija, Appeals Chamber Judgment, para. 184.
} 


\section{The Thin Line Between Being Wrong and Being Unprofessional}

The precise contours of ethical standards in international criminal proceedings become even harder to define when no precise written rules exist, as used to be the case for the OTP. As a matter of fact, unlike the judiciary and defense counsel, prosecutors have only recently been prescribed ethical rules: the ICC's Code of Conduct for the Office of the Prosecutor entered into force in $2013 .{ }^{18}$ However, just like defense lawyers, those working at the OTP come from diverse legal and cultural backgrounds, ${ }^{19}$ and the absence of a clear articulation of ethical and professional standards may create significant problems. On this point, the judgment of the ICTY Trial Chamber in Furundřja is again probably one of the most emblematic examples.

On December 10, 1998, the accused, Anto Furundžija, was found guilty on the counts of torture and outrages upon personal dignity, including rape, as violations of the laws and customs of war, contrary to Article 3 of the ICTY Statute. Moreover, he was found to have coperpetrated acts of torture and aided and abetted acts of rape. Between the first court appearance of the accused and the commencement of the trial, the ICTY Trial Chamber issued a formal complaint to the Prosecutor that dramatically illustrates the lack of common ethical standards amongst members of different national cultures. ${ }^{20}$

The Complaint related to the Prosecution's conduct regarding the disclosure of witnesses and other documentary material. Under the ICTY Rules of Procedure and Evidence, the Prosecution has extensive disclosure obligations. According to Rule 66(A)(ii), the Prosecutor shall make available to the defense "copies of the statements of all witnesses whom the Prosecutor intends to call to testify at trial, and copies of all transcripts and written statements taken," while Rule 68(i) requires the Prosecutor to, "as soon as practicable, disclose to the Defense any material which in the actual knowledge of the Prosecutor may suggest the innocence or mitigate the guilt of the accused or affect the credibility of Prosecution evidence."

In the Formal Complaint, issued on June 5,1998, the Trial Chamber expressed its dismay at what it considered to be conduct close to negligence in the Prosecution's preparation of the case. In particular, the Trial Chamber assessed that the Prosecutor had not complied with a Trial Chamber order or with the Rules of Procedure and Evidence with reference to the disclosure of witnesses and other documentary material. ${ }^{21}$ The Trial Chamber was particularly disturbed by the discovery that a witness statement from the main witness against the accused-Witness A—had been received by the Prosecution on November 1, 1997, but was only disclosed to the Defense on May 22, $1998 .^{22}$ The testimony of Witness A - a female Muslim civilian who had been arrested by members of a special unit of the military police that Furundžija commanded — was the centerpiece of the Prosecution's submission arguing that the acts of the accused constituted a crime of torture, as recognized in common Article 3 of the four Geneva Conventions of 1949. ${ }^{23}$ The discovery process, in the words of the Trial Chamber, exists "to enable the accused to examine, in advance of trial, the evidence against him and to build his defense to the allegations against him," 24 which the Prosecution's delay had not allowed. For these reasons, the Trial Chamber held that professionalism

${ }^{18}$ Int'l Crim. Ct., Code of Conduct for the Office of the Prosecutor (Sept. 5, 2013).

19 Arman Sarvarian, Professional Ethics at the International Bar 195, 203 (2013).

${ }^{20}$ Id. at 195 .

${ }^{21}$ Prosecutor v. Anto Furundžija, Case No. IT-95-17/1-PT, Formal Complaint, para. 9 (Int'l Crim. Trib. for the Former Yugoslavia, June 5, 1998).

22 Id.

${ }^{23}$ Prosecutor v. Anto Furundžija, Case No. IT-95-17/1-T, Trial Judgment, paras. 39-43 (Int'l Crim. Trib. for the Former Yugoslavia, Dec. 10, 1998).

${ }^{24}$ Prosecutor v. Anto Furundžija, Case No. IT-95-17/1-PT, Formal Complaint, para. 7 (Int'l Crim. Trib. for the Former Yugoslavia, June 5, 1998). 
required the Prosecution to be particularly diligent throughout the whole discovery process, which entails an especially high level of urgency and expediency given that the accused had been deprived of his liberty. ${ }^{25}$

In her response to the Formal Complaint, the then-prosecutor Arbour, vocally contested the qualification of her office's conduct as unprofessional:

I do not accept ... that any aspect of the conduct of counsel for the prosecution constituted misconduct amounting to the willful disobedience of court orders or deliberate and improper withholding of relevant evidence from the trial process. My review of the way the prosecution was handled confirms that there were failings on the part of the prosecution team, that errors of judgment were made. I have found no suggestion of bad faith on the part of any member of staff involved in the case. ${ }^{26}$

Where does one draw the line between misconduct and lack of professionalism, on the one hand, and simply taking an erroneous position on the law, on the other? In other words, when should we define conduct as unprofessional or unethical?

At the time of the complaint, the Prosecution was not subject to prescribed ethical rules, unlike the judiciary and defense counsel..$^{27}$ Arbour's argument was that "a decision not to disclose taken in good faith, on proper grounds, and representing an exercise of professional judgment on a difficult and novel issue may constitute an error of judgment but certainly does not amount to 'misconduct."'28 This statement illuminates how an individual's legal and cultural background can reveal itself. Arbour's argument reflects her own legal experience as a Canadian Supreme Court Justice. Canadian jurisprudence had developed in a way that perfectly supported her analysis of the ethical issues involved. In other words, her own culture, tradition, legal system, and professional background led her to interpret a given behavior as an "error of judgment."

However, the three Judges of the Trial Chamber, probably each reflecting his or her own culture and tradition, read the very same behavior as "misconduct."

\section{Whose Ethics? "The Transcendence of the Ego"29}

The disagreement over the proper characterization of the Prosecution's conduct in Furund₹̌i difficulties in creating a corpus of ethical standards that is genuinely shared by more than one hundred states and a wide variety of cultures and legal traditions. The absence of clear and precise standards risks creating a profound feeling of uncertainty around what is expected of each individual who participates in the proceedings. Codifying clear rules and thresholds, on the other hand, seems to reduce these risks, but only to a certain extent: the terms used in the various Codes are often vague and open to divergent interpretations, and because they are interpreted and applied by Tribunals on an ad hoc basis, they do not entirely eliminate unpredictability.

Besides, when ethical rules are codified, whose ethics do-or should — they reflect? There is a risk of "cultural hegemony" in the development and codification of ethical standards, to the extent that these standards develop in an environment dominated by a small number of countries and legal traditions. ${ }^{30}$ When the Code of Conduct and Disciplinary Procedure applicable to counsel appearing before the ICC was presented to the Court in May 2003, the

${ }^{25} \underline{I d}$., paras. 5, 6.

${ }^{26}$ Prosecutor v. Anto Furundžija, Case No. IT-95-17/1, Prosecutor's Response to the Formal Complaint of the Trial Chamber, para. 13 (Int'l Crim. Trib. for the Former Yugoslavia, Dec. 11, 1998).

27 In September 1999, after the end of the trial, the ICTY Prosecutor issued the Standards of Professional Conduct for Prosecution Counsel.

${ }^{28}$ Louise Arbour, Legal Professionalism and International Criminal Proceedings, 4 J. InT'L CRIM. Just. 674, 682 (2006).

29 Jean-Paul Sartre, The Transcendence of the Ego (1957).

${ }^{30}$ The accusations of neocolonialism were raised, e.g., in the Al Bashir case in front of the ICC. 
stated objective was to produce a code "that could be accepted and followed by Counsel from all cultures, traditions and legal systems and professional backgrounds." 31 No matter how good the intentions, a small yet crucial piece of the puzzle seems to be missing: to be able to follow and accept such emerging ethical standards, all cultures, traditions, and legal systems need to be concretely involved in their definition. Until then, the inherently relative nature of ethics will prevail and the "international judicial culture" that the international community is struggling to build will remain nothing more than a distant dot on the horizon.

${ }^{31}$ Statement of objectives, as quoted in Arbour, supra note 28, at 685. 